\title{
Imagining China in London Musical Theatre during the 1890s: The Geisha and San Toy
}

\author{
William A. EvERETT \\ University of Missouri-Kansas City \\ Conservatory of Music and Dance \\ 4949 Cherry Street, Kansas City, MO 64110-2229, USA \\ E-mail: everettw@umkc.edu
}

(Received: March 2016; accepted: June 2016)

\begin{abstract}
For people living in London during the 1890s, China and the Chinese were largely mythical constructions. Attitudes towards China, as well as the Chinese themselves, were being imagined at the time through various media, including popular musical theatre. Two shows, both with music by Sidney Jones and produced by George Edwardes at Daly's Theatre, were significant in this identity construction: The Geisha (1896) and San Toy (1899). Both musicals are set in East Asia and include Chinese and British characters. In The Geisha, which takes place in Japan, the sole Chinese character is Wun-Hi, the owner of a teahouse. He is less than honorable, and his music is in an ethnic-based music hall style, with nearly speech-sung melodies and unashamed Pidgin English. In Jones's score for San Toy, which is set in China, characters who endorse Western views sing glorious melodic lines reminiscent of Gilbert and Sullivan while those who do not sound like Wun-Hi in The Geisha, with clipped articulations and non-standard English.
\end{abstract}

Keywords: Orientalism, China, Operetta, The Geisha, San Toy

How the British imagined China and the Chinese at the end of the nineteenth century was a complex, multi-faceted, and sometime contradictory affair. London at the time had a Chinese population of only about 300, and most Londoners associated the Chinese with laundries, catering businesses, or opium dens. ${ }^{1}$ (Charles Dickens' The Mystery of Edwin Drood provides a vivid example for the last of these images, with its menacing atmosphere filled with mystery and unknowing.)

1. Sasch Auerbach, Race, Law, and "The Chinese Puzzle" in Imperial Britain (New York: Palgrave Macmillan, 2009), 6. 
But these were not the only ways in which the Chinese were viewed. In 1905 George Sims described the Chinese people living in London's East End as possessing "a most peaceable, inoffensive, harmless character."

These various attitudes toward China, as well as toward the Chinese themselves, were being manifested in various artistic products, including popular musical theatre. Two shows that originated at Daly's Theatre were especially significant in this identity construction in the final decade of the nineteenth century: The Geisha (1896) and San Toy (1899). In The Geisha, which takes place in Japan, the sole Chinese character is Wun-Hi, the owner of a teahouse, who sings (and speaks) in Pidgin English with clipped articulations. In the imagined China of San Toy, characters who endorse Western views sing glorious melodic lines reminiscent of Gilbert and Sullivan or comic opera while those who do not sound like Wun-Hi in The Geisha. In this theatrical version of Chinoiserie, China is evoked through visual, textural, and performative cues, not inherently musical ones.

The Geisha and San Toy are emblematic products of the Daly's Theatre enterprise, managed and produced under the creative eye of George Edwardes. Edwardes mounted five shows with scores by Sidney Jones at Daly's Theatre during the 1890s: A Gaiety Girl (1893, Prince of Wales; 1894, Daly's), An Artist's Model (1895), The Geisha, A Greek Slave (1898) and San Toy. All five shows are examples of the notoriously difficult-to-define genre of musical comedy. In the 1890s British sense of the genre, specifically how it was practiced at Daly's, aspects of comic opera - such as fanciful stories, nearly operatic singing, and multi-part ensembles - are melded with dimensions from burlesque and music hall, including improvisation and ethnic-based performance styles. This amalgamation resulted in a musical entertainment with broad popular appeal. Edwardes, whose prior experiences included working for Richard d'Oyly Carte at the Savoy Theatre and also managing the Gaiety Theatre, knew how to negotiate the space between comic opera and more fluid musical theatre genres. He used this liminality to create a particular brand of musical comedy at Daly's when he became its manager in 1895. The shows he produced at Daly's exuded opulence and romantic sentimentality while remaining steadfastly rooted in the everyday.

When it came to creating fanciful imaginings of East Asia in popular musical theater, Gilbert and Sullivan's The Mikado from 1885 remains the prime exemplar. Nearly a decade later, the Sino-Japanese War (1894-1895) shifted political relations in East Asia itself as well as those between Japan, China, and European powers. The war came to represent the enfeeblement of China's Manchu-descended Qing dynasty and Japan's modernization, along European lines, after the Meiji Restoration. Significant outcomes included Japan's acquisition of Korea and the field, 2015), 255. 
Liaodong Peninsula from China. ${ }^{3}$ The post-war "Triple Intervention" of Russia, France, and Germany, however, forced Japan to return the Liaodong Peninsula to China. Britain, notably, was not part of this European coalition and this decision led to closer relations between Britain and Japan and more strained ones between Britain and China. ${ }^{4}$

Thus, when The Geisha danced onto the stage at Daly's Theatre on April 25, 1896, it promoted a pro-Japanese and anti-Chinese view of East Asia. Billed as "A Story of a Tea House," The Geisha enjoyed an extremely long run of 760 performances in its initial production. Professional and amateur productions played throughout the world, either in English or in translation. Owen Hall's libretto for The Geisha revolves around several romantic relationships, all of which get sorted out at the end, thanks to the quick thinking of the geisha Mimosa and direct British intervention through the actions of Lady Constance Wynne. The Geisha was first staged in Budapest (as A gésák) in 1897, with several other productions following.

Wun-Hi, the owner of the teahouse where Mimosa works, is the only Chinese character in the show. He speaks in Pidgin English, an ethnic characterization associated with Yellowface and music hall. This distinguishes him from the Japanese characters, all of whom sing music in the more polished vein of Gilbert and Sullivan, which at the time was already being associated with notions of proper Britishness. Britain at the time was pursuing favorable trade relations with Japan and through musical style a shared cultural affinity was created between the two nations.

For China, though, the characterization was different, as is evident in WunHi's song "Chin Chin Chinaman." Pidgin English, mispronounced rs, exaggerated es, and a nasal sound all contribute to the negative caricature. Furthermore, The Geisha appeared during the period leading up to the Boxer Rebellion, and fears about violent uprisings against missionaries and other Westerners in China were very real. This is evident in the final three words of the refrain, vocalized in clipped articulation: "Chop, Chop, Chop."

The noted comic actor Huntley Wright (1868-1941), a veteran of burlesque and farce, created the role of Wun-Hi. Wright was Edwardes's lead male comic at Daly's Theatre during the 1890s and appeared in many productions at the esteemed house. His humorous stage presence, precise diction (including dialects), and harmless affect made him a favorite with audiences.

More nuanced depictions of China and the Chinese appear in San Toy, which opened at Daly's Theatre on October 21, 1899, and played for a stunning 768 performances. Like The Geisha, it toured extensively, though it did not enjoy the sustained popularity of its Japanese sibling. San Toy had its Budapest premiere in 1900.

3. Terms of the Treaty of Shimonoseki, which ended the conflict in April 1895, included Korea becoming a Japanese protectorate and China ceding Taiwan, the Liaodong Peninsula, and the Pescadore Islands to Japan. 4. The closer ties with Japan led to the signing of the Anglo-Japanese Alliance in 1902. 
Plate 1 Huntley Wright as Wun-Hi in The Geisha (Public domain)

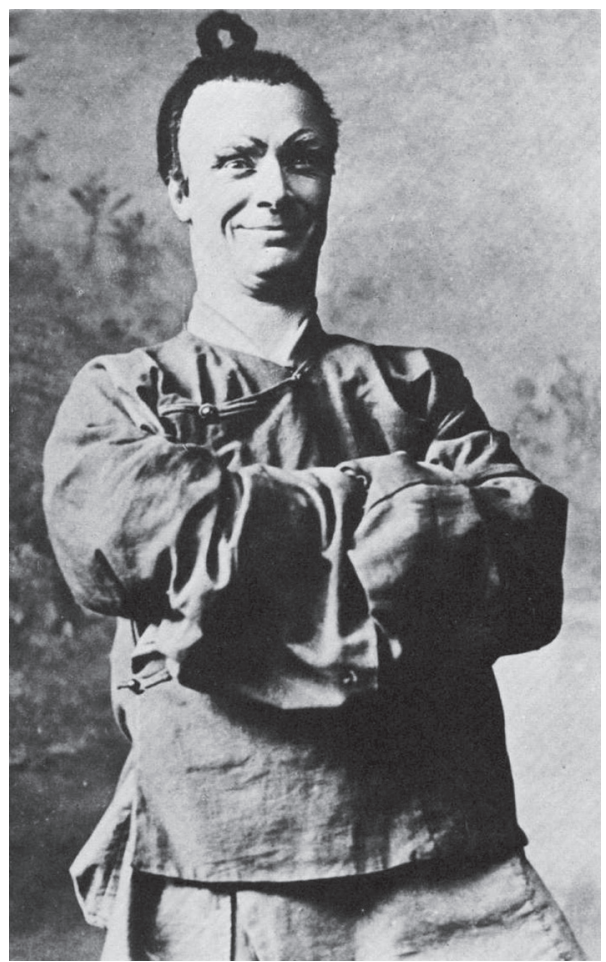

In the created China of San Toy, according to librettist Edward Morton, every noble daughter must join the Emperor's all-female regiment, the 'Emperor's Own." Pynka Pong's ruler, the Mandarin Yen How, evades this fate for his favorite daughter, San Toy, by having her raised as a boy. The student Fo Hop, however, discovers San Toy's gender and demands her hand in marriage for his silence. Yen How agrees, knowing that as long as no one knows that San Toy is a girl, the marriage cannot take place. Naval Captain Bobbie Preston, son of the British consul, has been teaching San Toy English, and knowing her gender, the two have fallen in love. The Emperor issues a new edict that now all noble sons must join a new regiment, "The Empress's Own," alongside the noble daughters. San Toy, resolving to be female, accompanies her still-secret lover, Bobbie, on a mission to Peking, along with her father.

Act 2 takes place in the Emperor's Palace. San Toy is introduced to the Emperor, who promises her that she will be treated with great favor. The Emperor soon decides that he wants to marry San Toy. Yen How, noticing this, dreams of becoming Viceroy and bringing British culture to China. By the end, the Emperor has decided to marry someone else, Yen How gives San Toy the choice of whom she will marry, she chooses Bobbie, and Yen How becomes Viceroy. 
Other characters in the show include Poppy, Bobbie's sister, whose conventional romance with Lt. Harry Tucker provides a foil for the plot's primary relationship; Dudley, Poppy's maid; and Li, Yen How's private secretary, a comic figure memorably created by Huntley Wright.

An overriding theme in San Toy concerns Westernization. Chinese characters who favor the West generally sing in a lyrical, comic opera style like the Japanese characters in The Geisha, while those who do not resort to the clipped style of Wun-Hi's "Chin Chin Chinaman."

These differences in attitude and their musical portayals are evident in the song "Samee Gamee," during which Dudley and Li explore differences between English and Chinese views of love. The two ultimately realize that love is never simple, regardless of culture. They each express concern about the other's perceived norm. Dudley regards Chinese polygamy as unfair, since a woman cannot have a complete man to herself, but only a fraction of him. Li retorts that English monogamy can lead to divorce. (Not incidentally, England loosened its divorce laws in 1885.) The differences in viewpoint are accentuated in the differences in performance style. Dudley, being English, gets to sing her lines, while Li, who is Chinese, only intones his (though he does sing in the refrain). Since he does not advocate Western norms, he refuses to speak (or sing) correct English.

Plate 2 Postcard of “Samee Gamee” from San Toy (Public domain)

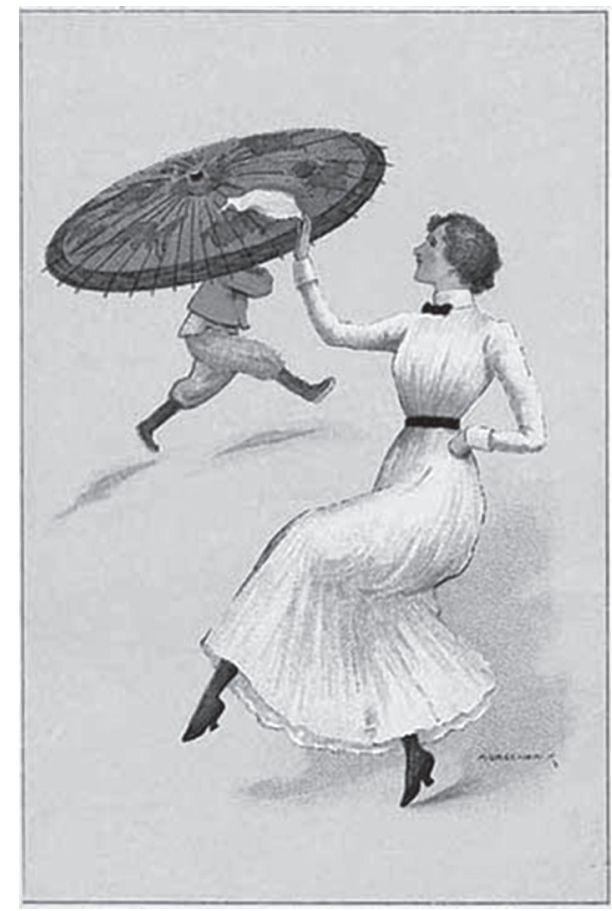


In the song "Pynka Pong," three secondary English characters, Poppy, Dudley, and Tucker, sing of their disdain at being in China, and Li reinterprets their complaints and tries to please them. While Pynka Pong appeals to tourists, they do not enjoy living there and see it as backward. Their attitudes endorse those promoted in collections of photographs from China that became extremely trendy in the late nineteenth century. These pictorial essays offered armchair travelers carefully chosen images to demonstrate various socio-political attitudes and viewpoints. Among these was the notion of China's stasis in the distant past and the country's unwillingness to modernize, except when the West forced it to do so. ${ }^{5}$ John Thomson, for example, in his Through China with a Camera (1899), remarks, "I will conclude this introductory sketch by expressing the hope that China may awake from her lethargy before it is too late..."

"Pynka Pong"'s musical setting likewise evokes aural images of a cultural hierarchy rooted in the past, for it harkens to minstrelsy through its dotted figures, unaccented syncopations, instrumental interjections, and call and response figures. References to a banjo in the lyrics leading into the final chorus strengthen the connection, which is made blatantly and uncomfortably obvious in said final chorus with references to cotton and Carolina:

There's something in the name of Pynka Pong,

Which doesn't seem exactly to belong

To the lazy land of China,

For it smacks of Carolina,

And the sugar cane and coon and cotton song.

Blackface minstrelsy was present on London stages in the late nineteenth century, and the creators of San Toy drew upon the style to demonstrate how three British characters with racially superior attitudes felt about being in China. It also reflects the contradictory fear and attraction toward cultural otherness that Eric Lott has described in terms of minstrelsy and which Derek B. Scott has tied into London minstrelsy practices.?

For Yen How, who is proud to be Chinese and advocates Western cultural practices, the musical stylization is different. We learn in his introductory number that he appreciates British ways, for he sings music in a Gilbert and Sullivan style. This part, not incidentally, was created expressly for Rutland Barrington (1853-1922), who created such iconic Gilbert and Sullivan roles as Captain Cor-

5. For a thorough discussion of these photographic imaginings of China and their interpretations and influences, see Elizabeth Hope Chang, chapter 4, "Photograph," in Britain's Chinese Eye: Literature, Empire, and Aesthetics in Nineteenth-Century Britain (Stanford: Stanford University Press, 2010), 141-178.

6. John Thomson, Through China with a Camera (London and New York: Harper \& Brothers, 1899), 17.

7. Derek B. Scott, Sounds of the Metropolis: The 19th-Century Popular Music Revolution in London, New York, Paris, and Vienna (Oxford and New York: Oxford University Press, 2008), 168. 
coran in H.M.S. Pinafore, the Sergeant of Police in The Pirates of Penzance, and Pooh-Bah in The Mikado. "Six Little Wives" is a rollicking romp in 6/8 featuring responsorial interjections from his six wives. But Yen How also shows that he is not wholly Westernized, for he practices polygamy and, furthermore, once he kills off each of his six wives, he will acquire a dozen new ones! Additionally, he is dishonest, having cheated on an exam by sewing answers into his clothing.

The musical asserts that the Chinese themselves need to have an active role in the nation's modernization along Western lines. Yen How offers his help, should he become Viceroy, in his act 2 semi-satirical song, "I Mean to Introduce It into China":

So we'll emulate the styles

Of the blessed British Isles,

Though the reason isn't easy to divine - Ah!

But they do it in the West,

So of course it must be best,

And I mean to introduce it into China!

This Westernization plotline could allude to the actual Hundred Days' Reform of 1898, during which the Guanxu Emperor tried to implement an extensive reform program with the aid of his Western-oriented Viceroy, Li Hongzhang (a model for Yen How's character in this regard). The plan did not succeed, for the Emperor's aunt, the Empress Dowager, put him under house arrest, where he remained until his death.

Yen How's attempt to Westernize his daughter by making her dress as a boy (masculinize her) follows the tenets of Orientalist discourse at the time. In many studies of Orientalism, such as those of Edward W. Said, ${ }^{8}$ the West views the East as feminine, an Other to its own masculinity. In this reading, Yen How wants his daughter to be male, and therefore Western. Furthermore, following general tenets of Orientalism, the Chinese army is all female in the first act. The Emperor wants to strengthen his army, to Westernize it, by conscripting noble men. Despite his efforts, no change in its actual status occurs. To the Western creators and audiences the Chinese army, like Asia itself, remains a feminine construct.

San Toy's China is similarly viewed as a commodity to be bought and sold. During the nineteenth century, a fashionable notion of an imagined China was seen, literally, in the popular willow design of English-produced Wedgwood porcelain (see Plate 3). Stories were created in England to explain the features of

8. See Edward W. Said, Orientalism (New York: Pantheon, 1978) and the same author's Culture and Imperialism (New York: Knopf, 1993). 
the pattern. One of the most popular told of a wealthy mandarin who did not like his daughter's romantic choice, a humble accountant. The mandarin built a high fence around his house to keep them apart. On the day the daughter was to marry a powerful Duke, the accountant snuck in and helped his true love escape to a secluded island. The mandarin tracked them down and had them both killed. The Gods then transformed the lovers into a pair of doves.

Plate 3 Willow pattern plate (author's collection)

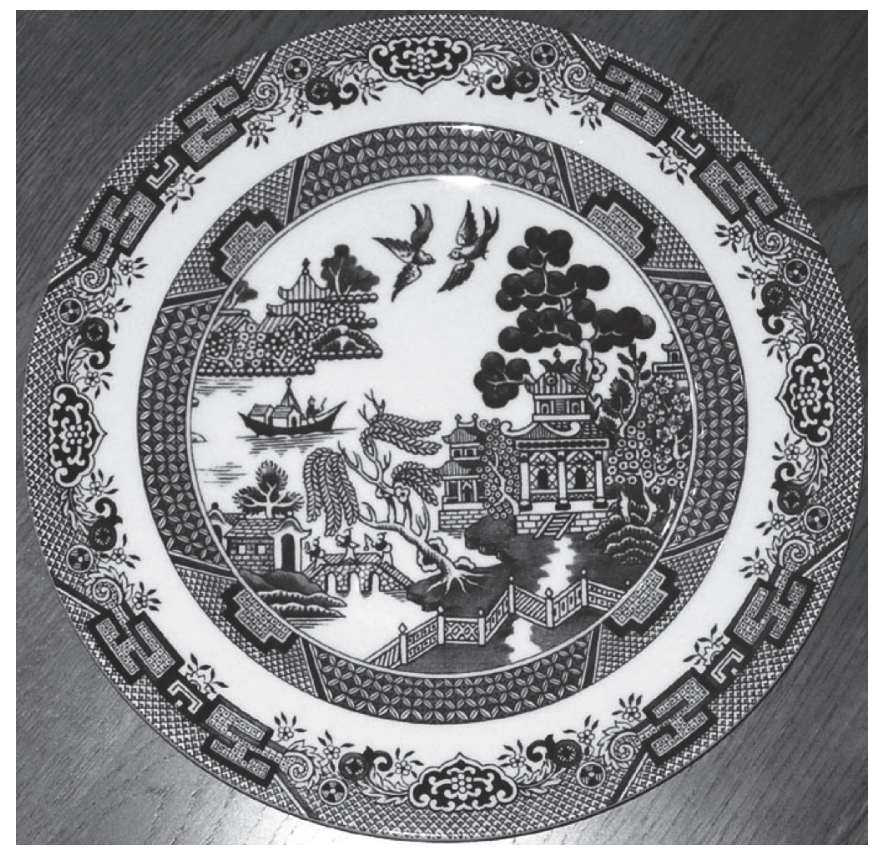

By the mid-nineteenth century, such willow patterns began to represent domestic middle-class Britishness, as Elizabeth Hope Chang demonstrates in her book Britain's Chinese Eye. By the end of the century, the familiar blue and white had gained a nostalgic tinge, and still connoted, according to Chang, "an enduring and unchanging British domesticity simply in its appearance on tea-table or in a china-cupboard." 9

In their lilting act 2 duet, "The Little China Maid," San Toy and Bobbie both make references to porcelain. Bobbie tells San Toy, when she expresses concern about them being together: 
You needn't feel afraid,

For like a vase or cup,

I'll pack you completely

And label you neatly

With "China, this side up!"

Bobbie is certainly viewing San Toy as a commodity. Later in the song, she expresses a concern:

But when you have me there

Entirely to yourself,

You'll shatter your passion

In porcelain fashion,

Or leave me on the shelf.

He promises, in reference to the color of the plate, not to do so and that he will always "stick to Nankin blue!" Such references offer examples of what Dongshin Chang labels an interculturated form of Chinoiserie - depicting Chinese motifs, but not Chinese reality, in a relatable British context. ${ }^{10}$

The final British view of the Chinese to be considered in San Toy comes from the Boxer Rebellion, or Boxer Uprising. This series of violent anti-foreign and anti-Christian demonstrations began on November 2, 1899, less than two weeks after the premiere of San Toy. The Eight-Nation Alliance (which included Japan, the U.K., and the U.S.) defeated the Chinese in 1901, strengthening Japan's prestige in world affairs and further weakening the already enfeebled Qing Dynasty.

As a British musical set in China at the time of the Boxer Rebellion, it comes as no surprise that some Chinese characters exhibit violent tendencies. A precursor of this depiction occurs in The Geisha's "Chin Chin Chinaman." The exemplar in San Toy is Fo Hop, the student who wants to marry San Toy. In "When You Are Wed to Me," he sings to his betrothed, "By being quite Chinese, Each Western trick I ban with sharp and quick rattan!"

But what about the show's ending? San Toy (China) decides to marry Bobbie (the West). This interracial union at the end of San Toy could be interpreted as an allegory for the hope of an eventual reconciliation between China and Britain in terms of political and commercial diplomacy. In San Toy, Sir Bingo Preston, Bobbie's father, tries to interest Yen How in a railroad concession, a commercial interest that would have competed with Russia's real-life railroad expansion in Asia at the time. Perhaps because of the marriage between their children, Sir Bin-

10. Dongshin Chang, Representing China on the Historical London Stage: From Orientalism to Intercultural Performance (New York: Routledge, 2015), 60, 77. 
go may be able to realize his entrepreneurial goal. Taken literally, the interracial marriage transgresses 1890s norms. But when we remember that these are "play actors" (no one in the cast is really anything but British), the show ends with its beloved stars being together.

The depiction of China in The Geisha and San Toy offers multiple approaches rooted in shifting cultural attitudes and political situations. Characters who do not support Western views are relegated to performing in ethnic-based styles coming from music hall while those who do sing lyrical melodies in proper English. No one sings any actual Chinese music nor are any of the standard Orientalist identifiers employed. What does happen is that the anti-Western characters become villains of sorts for whom dishonesty becomes a character trait. (This stereotype of the evil Chinese individual became further codified in Sax Rohmer's Fu Manchu novels of the early twentieth century.) But other characters do want to establish ties with the West, and in this world of popular musical theatre, they demonstrate this affinity by singing in a lyrical style firmly in line with the respectability and moral fortitude associated with Gilbert and Sullivan. 